\title{
22. The structure of and changes to China's land system
}

\section{Shouying Liu}

Institutional arrangements for landownership are fundamental to China's political and economic system. Landownership is a key and sensitive area of China's overall reform. China's unique land institutions and changes to them are central to the country's rapid economic growth and structural change.

Reform of the rural land system in the early 1980s marked the beginning of China's reform and opening-up, promoting its rural transformation and economic transition. Changes to the urban land system since the late 1990s have promoted China's historic shift from a rural country to an urban-rural society.

This chapter has five parts. The first briefly introduces the structural characteristics of China's land institutional arrangements. The second analyses the process of reform of the land system in the past 40 years and its path of change. The third discusses the historical contribution made by land institutional changes to China's rapid economic growth and structural change. The fourth gives a schedule of further land reform in the new development stage, while the final section concludes by providing some policy implications.

\section{The structure of China's land institutions}

The Chinese land system is a complete institutional structure, covering arrangements for farmland, land conversion and urban land use.

\section{Farmland household contract system under collective ownership}

Rural contracted land covers the largest share of total land and involves the largest proportion of the population. At the end of 2015, China had a total of 645.5 million hectares of agricultural land, 135 million hectares of which were farmland (Ministry of Land and Resources 2016). A total of 134.2 million hectares-accounting for 99.4 per cent of total farmland-were contracted to 23 million households ( $\mathrm{Qu}$ 2015). The rural contracted land system was seen as a basic arrangement influencing agricultural performance, farmers' rights and social stability. 
China's rural land system is unusual in the world and has thoroughly changed the countryside. In traditional rural China, farm households privately owned land, farming was undertaken mainly by self-employed family units and tenant farmers were the main operators of small farms. The ownership and management rights to the farmland were protected by law and contracts, while the cultivation rights, to a large extent, had the de facto attributions and functions of ownership (Fei and Liu 2007).

After the Communist Party of China (CPC) came to power, it installed socialism based on public ownership, promoting China's transition from a rural to an industrial economy (Mao 1991). For this purpose, the new regime created a series of state-led systems in rural areas (Du 2005), forming a unique collective rural landownership system, which had the following characteristics:

1. As a form of public ownership in rural areas, collective ownership was applied to rural land and the state implemented comprehensive political and economic control over rural areas through people's communes, production brigades and production teams.

2. The state exercised collective land property rights. Senior officials controlled the land use rights in production teams. Production teams were not entitled to select the land to be planted, and the right to revenue was truncated due to procurement by the state. Public investment and distribution to production team members were conditioned by the requirement to first complete tasks assigned by the state.

3. Agricultural economic activities and labour were arranged in a unified way by the production team, and production results were distributed in a uniform way based on work points (Zhou 1995).

The change in the political climate and recognition of the inefficiency of statecontrolled collective ownership and unified operations saw China launch rural land reform in the late 1970s and early 1980s. Through grassroots innovations, official support and policy implementation (Rural Development Group 1984), a new rural land system acceptable to the relevant agents was formed. Rural land was to be owned by collectives and contracted to village households. The premise of the reform was collective landownership under a socialist system. At this point, the state produced numerous documents to declare collective ownership unchanged. First, land contracted to each household did not equate to private ownership (CPC Central Committee 1982). The collective ownership framework followed 'three levels of ownership, with the production team as the basic unit'. The relationship between peasants and the land was defined as a contractual one. Under collective ownership, rural land could not be bought or sold. Second, contracts were formed between the state, collectives and households. The initial contract arrangement was tacitly selected by farmers - something later regarded as a tripartite contract. The contract 
was meant to ensure the farm household was contributing adequately to the state, paying enough to the collectives and retaining any remaining production. After fulfilment of their national tasks and collective obligations, farmers could retain the residual claim of the collective land. Third, collective ownership was explicitly defined as ownership by all members, which differed from the 'commune members' in the collective farming period. Whereas commune members were provided with a certain income, the 'collective members' under the household responsibility system (HRS) could enjoy rights to all income from products grown on collective land. Collective ownership after the reform strengthened the identity of collective membership. Fourth, the clarification of property rights in the contracting of farmers on agricultural land separated collective ownership from the right of use, creating a real contracting right, strengthening the dominant position of farmers, improving farmers' right to use the contracted land and granting them rights to revenue and transfers. Fifth, as a result of the elimination of the farming system under which production teams organised production and distributed revenue, families replaced the production teams as the unit of agricultural production and in economic decision-making and income allocation. Farming households then became the operating entity of agricultural management. This was institutionalised by law.

\section{Land conversion arrangements under dual ownership}

In the past 40 years, China's high-speed economic growth has been accompanied by rapid industrialisation and urbanisation. From 2003 to 2015, 11.6 million hectares (Ministry of Land and Resources 2004, 2016) of agricultural land were converted to nonagricultural rural and urban construction land. The change of ownership was achieved both by conversion by the collective and by expropriation by the government.

From the beginning of rural reform until the revision of the Land Administration Law in 1998, the channel for the conversion of agricultural to collective construction land was open. In the early 1980s, a large number of surplus workers were released by agricultural reforms and the government encouraged farmers to use collective land to set up township and village enterprises (TVEs). As a result, the amount of rural construction land increased rapidly. Land utilised by TVEs in China was estimated to be 15,700 hectares in 1978 and about 56,300 hectares in 1985. From 1981 to 1985 , an average of more than 600 million sq m per annum was used for new farmers' residences.

Until 1987, when the Land Administration Law was first implemented, there were three channels for converting rural land to nonagricultural construction land. First, as long as the construction conformed to the construction plan of the township (or village) and the county government's approval was obtained, rural residential construction, TVE construction, township (village) public facilities, public welfare 
construction and other township (village) construction could be carried out. Second, in the event that a collective agricultural economic organisation needed land to organise joint ventures with enterprises owned by the people, or collectively owned enterprises, it was allowed to requisition the land in accordance with the provisions of the state construction requisitions. The agricultural collective economic organisation could also, according to the contract, use the land use rights as its contribution to joint management. Third, residents with nonagricultural household registration (bukou) could use the collectively owned land for residential construction, with approval from the county government (Liu 2008a).

Land requisition was the main tool for conversion of agricultural land to nonagricultural use. In particular, after the channel for the conversion of collective construction land was closed, expropriation was the only legal path for land conversion. China's 1982 constitution backed the principles in the 1954 constitution in which the state may, in the interests of the public, conduct land requisition; however, it also put forward for the first time the idea that urban land would be owned by the state while collectives would own rural land. This established a dual landownership system. ${ }^{1}$ The Land Administration Law promulgated in 1987 required that land conversion be based on the public interest. The definition of public interest was broad: the state could conduct land requisition for economic, cultural, national defence and social and public undertakings. Compensation was based on the principle of original use. The levels of compensation and resettlement subsidies were raised to no more than 20 times the average annual output of the three years prior to the requisition of the land. Employment and hukou status were provided to the peasants whose land was taken. ${ }^{2}$

\section{Urban land use under state ownership}

Before reform, China implemented a system of free and indefinite access to land. The Land Administration Law of 1987 stipulated two types of land use modes: administrative allocation and paid transfer. The institutions governing urban land use after conversion to state ownership not only provided land security for the rapid advancement of industrialisation and urbanisation, but also were an important source of capital for urban construction.

1 Refer to the Constitution of the People's Republic of China, adopted at the Fifth Session of the Fifth National People's Congress, 4 December 1982.

2 Refer to the Law of the People's Republic of China on Land Administration, Adopted at the Sixteenth Session of the Standing Committee of the Sixth National People’s Congress, 25 June 1986. 


\section{Land institutional change in the reform era}

\section{Strengthening farmers' property rights}

\section{Legally clarifying collective ownership}

China's Rural Land Contract Law and Property Law defined collective ownership as 'land collectively owned by peasants in rural areas that is fundamental to the basic rural operation system' ${ }^{3}$ and 'the collective owner of collective land, in accordance with the law, is entitled to possess, utilize, dispose and obtain profits from the collective land'. ${ }^{4}$ The 'peasant collective', as the subject of landownership, had three levels: the village peasant collective, the intravillage peasant collective and the township peasant collective (Wang and Zhou 2012).

\section{Improving farmers' property rights for contracted land}

Land contract rights are a special type of property usage right, and contracted land is the farmer's property (Liu 2002). Legislation clearly states that contracting farmers are entitled, in accordance with the relevant law, to use and obtain profits from the contracted land, to transfer the land contract rights and to organise production, operation and disposal of products. If contracted land is expropriated by law, the contractor has the right to receive appropriate compensation. ${ }^{5}$ During the contract period, the collective cannot recover or adjust the contracted land so as to continuously extend the right to subcontract. ${ }^{6}$ To restrict any infringement of farmers' land property rights, it is expressly stipulated that within the statutory period of the contract, no organisation or individual shall interfere in farmers' production and management autonomy, the contracted land shall not be unlawfully adjusted or claimed, the wishes of farmers shall not be contravened by forcing the transferral of the contracted land and farmers shall be protected from illegal encroachment on contracted land (State Council 2004).

\section{Extending the land contract period for farmers}

The initial land contract period of 15 years in 1984 (CPC Central Committee 1984) was extended to 30 years for the second contract period (CPC Central Committee 1993). The third plenary session of the fifteenth Central Committee of the CPC held in 1998 granted farmers long-term and guaranteed land use rights (CPC Central Committee 1998). During the third plenary session of the

3 Refer to the Law of the People's Republic of China on Land Contracts in Rural Areas, Adopted at the Twenty-Ninth Session of the Standing Committee of the Ninth National People's Congress, 29 August 2002.

4 ibid.

5 ibid.

6 ibid., s. 26. 
seventeenth Central Committee, a proposal was made that contracting farmers' land rights could not be changed for a long time (CPC Central Committee 2008). The third plenary session of the eighteenth Central Committee reaffirmed this provision (CPC Central Committee 2013).

\section{Redefining membership rights of collective ownership}

The Central Rural Policy Research Office conducted a pilot experiment in Meitan county, Guizhou province, in the late 1980s, in which neither an increase nor a reduction in family members led to an increase or reduction in the land for that family. In 2002, the pilot results were written into the Rural Land Contract Law, which clearly says that the state will protect the long-term stability of the rural land contract and that within the contract period, the collective will not adjust the contracted land.

\section{Changing the contract conditions}

The government's obligations in relation to farmland were changed gradually. First, the amount of grain to be provided to the state by farmers was reduced. Initially, farmers were entitled to plant freely beyond their quota and to exchange food for currency. This reduced the linking of farmers' land to grain quotas. Second, the central government implemented grain marketing system reform, with the state buying grain in a market-oriented way. Grain quotas were terminated and the state provided farmers with grain subsidies. Collective obligations changed. In the 1990s, farmers had to contribute to a collective accumulation fund and a public welfare fund. The assessment burdens on contracting farmers were overwhelming. Subsequently, the 'one act, one discussion' method was adopted. ' The farmer's obligation was not linked to the contracted land. Changes in state and collective obligations amplified the residual claim of farmers' land rights (Zhou and Liu 1997).

\section{The family farming system as a constitutionally approved system}

In 1991, the Chinese Government proposed that, for the first time:

[T] he two-tier management system based on household contract management that combines unification and separation shall be stabilized in the long term, and constantly enriched and perfected as a basic system of the Chinese rural collective economic organization. (CPC Central Committee 2008)

7 An example of this is when a village decides to provide any item of public goods, each decision is made after a village consultation. 
The Chinese constitution of 1999 explicitly states that 'rural collective economic organizations [must] implement the two-tier management system based on household contract management and combining unification and separation'. The Law on the Contracting of Rural Land in 2002 formally proposed the national implementation of the rural land contract management system. In 2008, the third plenary session of the seventeenth Central Committee of the CPC announced:

[T] he two-tier management system based on household contract management combining unification and separation is suitable for the Socialist market economy, which is in line with the characteristics of the basic rural management system for agricultural production, constitutes the cornerstone of the party's rural policies, and must be unwaveringly adhered to. (CPC Central Committee 2008)

\section{Local government monopolises land conversion}

Since 1992, China has changed its policy on land conversion to cover collective construction activities. Rural land has to go through requisition and transfer as stateowned land when it is to be used for construction (CPC Central Committee 1992). The revised Land Administration Law, promulgated in 1998, legally restricted the conversion of agricultural land into collective nonagricultural construction land, excluding farmers from using collective land for nonagricultural construction, except for the

use of land collectively owned by peasants of the collective economic organization approved in accordance with the law for the establishment of township and village enterprises and construction of residences by villagers, or use of land collectively owned by peasants approved in accordance with the law for the construction of village (township) public facilities. ${ }^{8}$

The law stipulated that 'the right to use of land collectively owned by peasants shall not be transferred, retransferred or leased for non-agricultural construction', and it retained the provision that 'rural collective economic organizations may jointly organize enterprises with other units and individuals in the form of equity participation of land use rights and joint operations' .

The law followed the principle of land requisition for public use, the structure of urban and rural dual ownership and the original-use-based compensation principle, but the limit on land compensation and resettlement subsidies was raised to no more than 30 times the land's average annual output for the three years prior to the requisition of the land. This law also made two provisions that had a significant

8 Refer to the Law of the People's Republic of China on Land Administration, Revised and Adopted at the Fourth Session of the Standing Committee of the Ninth National People's Congress of the People's Republic of China, 29 August 1998.

9 ibid. 
impact on land conversion, the first of which was the establishment of the 'land use control system', through which the government formulates a general plan for land use, stipulates use for land, controls the total amount of land used for construction and examines and approves annual quotas of construction land. ${ }^{10}$ Second, if any unit or individual wishes to use land for construction, they must apply for the use of state-owned land in accordance with the law. ${ }^{11}$

China's problems with land requisition became more and more serious as the process of industrialisation and urbanisation accelerated. The Ministry of Land and Resources began a pilot reform of the land requisition system in 2001. ${ }^{12}$ After 2003, the central government called for reform of the land expropriation system. The content and direction of the reform of land requisition were meant to safeguard the rights and interests of farmers, control the scale of land requisition, improve land requisition procedures and strictly define public and business uses. The third plenary session of the eighteenth Central Committee decided to make general reforms to the land system, including allowing rural collective construction land to be leased, transferred and to share profits of collective construction. This land then enters the market with prices and rights identical to those for state-owned land. To narrow the scope of land expropriation, land requisition procedures would be standardised and the safeguards for farmers whose land was requisitioned would be improved to be reasonable, standardised and multivariate. The range of paid uses of state-owned land would be expanded and the allocation of non-publicwelfare land would be reduced; the secondary market for land leases, transfers and mortgages would be improved; and a reasonable mechanism would be established to adjust the price ratio of industrial land to residential land and raise the price of industrial land. A pilot program incorporating the above measures was carried out across the country (CPC Central Committee 2011). Reform of the rural land system officially began at the thirteenth session of the Standing Committee of the Twelfth National Congress of the CPC on 27 February 2015. This session adopted the State Council's decision to authorise the adjustment of legal provisions in 33 pilot counties (State Council 2015) and implemented the council's 'Opinions on Rural Land Expropriation' (State Council 2014).

10 ibid.

11 ibid.

12 Since 2000, Heilongjiang province has practised unified annual production for the main types of land requisition in each city and county. Hangzhou City in Zhejiang province and Nanjing City and Suzhou City in Jiangsu province no longer estimate compensation fees; rather, comprehensive consideration of land use, location, local economic development level, land supply and demand and other factors, combined with the level of social security of local urban residents, is used to determine land requisition compensation standards. 


\section{Capitalisation of urban land}

On 1 December 1987, land use rights for 50 years for a lot of 8,588 sq m was publicly auctioned in Shenzhen - the first time land use rights had entered the market as an asset (Liu 2008b). Amendment of the Chinese constitution in April 1988 deleted the provision preventing land being rented and added a provision that allowed land use rights to be transferred in accordance with the provisions of the law. In May 1990, the State Council issued its interim regulations on the granting and transfer of rights to use state-owned land in cities and towns, which clearly stipulated that land use rights could be transferred in three ways-by agreement, bidding and auction.

The Land Administration Law of 1998 clearly stipulated that land use rights could be transferred in accordance with the law and the state would implement a system of paid use of state-owned land. The central government, as a representative of the landowner, would transfer state-owned land use rights within a certain period-by agreement, bidding or auction - to the land users, who would pay the government for those land use rights in accordance with the assignment contract. Since 1999, the paid land use system has been further reformed, reducing the proportion of allocated land and increasing the proportion of paid use land.

In May 2002, the Ministry of Land and Resources issued its 'Provisions on the Assignment of State-owned Land Use Rights', stipulating that land to be used for business, tourism, entertainment, commercial housing and so on must be transferred by bid tendering, auction or listing (Ministry of Land and Resources 2002). The total land area and value transferred by bid tendering, auction and listing increased from 6,600 hectares and RMB49.2 billion, respectively, in 2001, to 66,500 hectares and RMB549.2 billion in 2006 (Liu 2012). After the State Council's Document No. 28 of 2004 was issued-stipulating that the transfer of industrial land must be carried out by bidding, auction or listing - the proportion of state-owned construction land transferred by these means rose annually. In the period 2001-10, the proportion increased from 7.3 per cent to 88.3 per cent. Bidding, auction and listing accounted for 92.2 per cent of total revenue from land sales in 2010 (see Table 22.1).

Under the current land system, the government not only is the sole arbiter in the transformation of rural land into urban land, but also the only winner of the valueadded income of the land in the process of land conversion. With land conversion, the government replaces the peasant collective as the owner and operator of the urban land. This has become the main tool for land development (Liu 2012). 
Table 22.1 Total transferred land and the share of land transferred by bidding, auction and listing (BAL), 2001-15

\begin{tabular}{|c|c|c|c|c|c|c|}
\hline & \multicolumn{4}{|c|}{$\mathrm{BAL}$} & \multicolumn{2}{|c|}{ State-owned land transfer } \\
\hline Year & $\begin{array}{c}\text { Area } \\
(10,000 \mathrm{ha}) \\
\end{array}$ & $\begin{array}{c}\text { BAL } \\
\text { percentage }\end{array}$ & $\begin{array}{c}\text { Price } \\
\text { (RMB billion) }\end{array}$ & $\begin{array}{c}\text { BAL } \\
\text { percentage }\end{array}$ & $\begin{array}{c}\text { Area } \\
(10,000 \mathrm{ha})\end{array}$ & $\begin{array}{c}\text { Price } \\
\text { (RMB billion) }\end{array}$ \\
\hline 2001 & 0.7 & 7.3 & 49.2 & - & 9.0 & - \\
\hline 2002 & 1.8 & 15 & 96.9 & - & 12.0 & - \\
\hline 2003 & 5.2 & 27.8 & - & - & 18.7 & 293.8 \\
\hline 2004 & 5.2 & 29.2 & 325.4 & 55.2 & 17.9 & 589.4 \\
\hline 2005 & 5.7 & 35.0 & 392.0 & 71.2 & 16.3 & 550.5 \\
\hline 2006 & 6.6 & 28.6 & 549.2 & 71.5 & 23.2 & 767.7 \\
\hline 2007 & 11.5 & 50.9 & $1,007.5$ & 82.5 & 22.6 & $1,221.7$ \\
\hline 2008 & 13.4 & 81.9 & 952.9 & 92.9 & 16.3 & $1,026.0$ \\
\hline 2009 & 18.8 & 85.3 & $1,509.8$ & 94.9 & 22.1 & $1,591.0$ \\
\hline 2010 & 25.7 & 88.3 & $2,600.0$ & 95.9 & 29.1 & $2,710.0$ \\
\hline 2011 & 30.5 & 91.2 & $3,020.0$ & 95.9 & 33.4 & $3,150.0$ \\
\hline 2012 & 29.3 & 90.8 & $2,550.0$ & 94.8 & 32.3 & 2,690.0 \\
\hline 2013 & 33.9 & 92.3 & $4,040.0$ & 96.2 & 36.7 & $4,200.0$ \\
\hline 2014 & 25.1 & 92.5 & $3,180.0$ & 95.2 & 27.2 & $3,340.0$ \\
\hline 2015 & 20.4 & 75.2 & $2,860.0$ & 85.6 & 22.1 & $2,980.0$ \\
\hline
\end{tabular}

- no data available

Sources: Ministry of Land and Resources (2004, 2016).

\section{Land system change and economic growth}

Land system change has had a major impact on China's economic growth since 2008. Agricultural land reform has promoted the growth of agricultural production and released a large portion of the population from villages, providing a microfoundation for China's economic transformation. Although strict farmland protection has been implemented, the ample supply of land in regions with development opportunities has supported high economic growth. Local governments have used distorted industrial land prices and land supply to attract investment to provide industrial park infrastructure, which has contributed to rapid industrialisation and made China a world-class manufacturing factory. Land capitalisation and land financing have provided much of the enormous amount of capital for China's urban development and promoted rapid urbanisation. 


\section{Land is the engine that drives China's high economic growth}

China's traditional development model relies on high growth and high investment. Because municipal and county governments are the real landowners, land has been the main tool for local governments to promote investment and growth. Over the past 40 years, land has had two roles: to safeguard national food security and to support high growth. To pursue growth in gross domestic product (GDP), an ample supply of land for expanding activities was required. During the period 2003-12, the total annual supply of state-owned construction land increased from 286,400 hectares to 690,400 hectares — an average annual increase of 10.3 per cent. The supply of land increases when economic growth slows (see Figure 22.1). Regional land supply policy underpins growth. Before the Global Financial Crisis (GFC), coastal regions with large demand for land experienced rapid growth in land supply in areas with rapid economic growth. Under the annual plan, scarce local construction land quotas were used mostly for the development of capital cities and major development zones. The flexible supply of construction land under strict farmland protections ensured high economic growth.

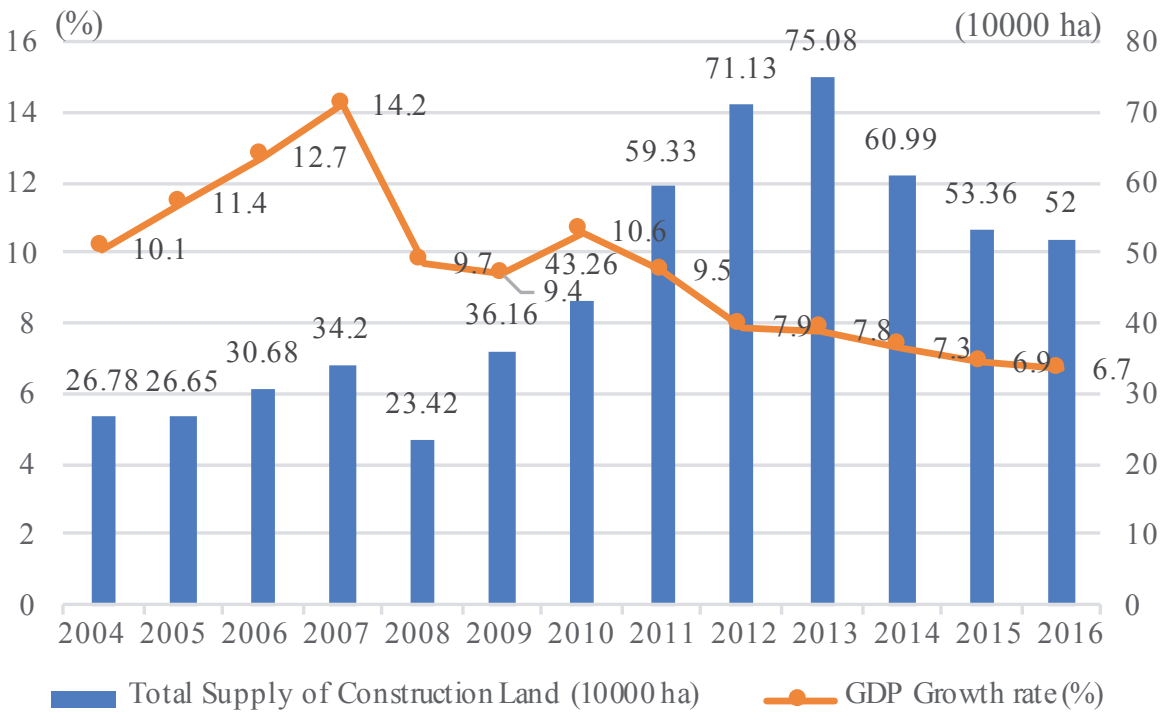

Figure 22.1 Supply of construction land versus GDP growth rate Sources: Ministry of Land and Resources (2004, 2016); NBS (various years). 


\section{Farmland reform and agricultural transformation}

A stable and efficient rural land institution was a prerequisite for overall reform and structural change in the past 40 years. Rural land reform improved land use efficiency in the direction of clarifying property rights, but also made it possible to launch structural change in rural areas.

First, the household responsibility system was established and persisted in agriculture, becoming the foundation of China's agricultural growth. This system was generalised from 1984. In 2016, despite the growth of new types of agricultural management, family contracted land still accounted for 99.4 per cent of all cultivated area. The production of food crops increased from 407.3 million tonnes in 1984 to 616.2 million tonnes in 2016, which can be attributed to the progress of agricultural technology, the increase of modern investment and the stability of the family management system.

Second, the reconstruction of human relationships with the land has promoted structural transformation. In traditional rural China, farmers were tied to the land. During the state industrialisation period, peasants were excluded from the process of industrialisation and were bound to collectively owned land. After implementation of the family contract system, peasants were able to participate in the local industrialisation of rural areas and subsequently to go out from their villages to participate in the industrialisation of other areas, becoming the main force to promote China's structural revolution.

Rural institutional reform and structural change promoted the transformation of the agricultural development model. The transfer of farmland increased, reaching 36 per cent in 2016. The balance of agricultural inputs shifted from labour to machinery. The focus of agricultural development has shifted from improvement of land productivity to improvement of labour productivity (see Table 22.2).

Table 22.2 Land system versus agricultural transformation

\begin{tabular}{|l|r|r|r|r|r|r|}
\hline Year & 2010 & 2011 & 2012 & 2013 & 2014 & 2015 \\
\hline $\begin{array}{l}\text { Proportion of rural household } \\
\text { contracting (\%) }\end{array}$ & 94.1 & 94.4 & 96.89 & 98.1 & 98.4 & 99.4 \\
\hline Farmland transfer rate (\%) & 14.7 & 17.8 & 21.25 & 25.7 & 30.3 & 33.3 \\
\hline $\begin{array}{l}\text { Proportion of rural residents } \\
\text { going out (\%) }\end{array}$ & 58.3 & 59.5 & 59.87 & 61.6 & 63.2 & 63.7 \\
\hline $\begin{array}{l}\text { Proportion of agricultural net } \\
\text { income (\%) }\end{array}$ & 29.1 & 27.2 & 26.6 & 26.5 & 25.7 & 25.1 \\
\hline $\begin{array}{l}\text { Total power of agricultural } \\
\text { machinery (million kWh) }\end{array}$ & 927.8 & 977.3 & $1,025.6$ & $1,039.1$ & $1,080.6$ & $1,117.3$ \\
\hline Land productivity (kg/ha) & $4,973.6$ & $5,156.9$ & $5,301.8$ & $5,376.6$ & $5,385.1$ & $5,984.0$ \\
\hline Labour productivity (kg/person) & $1,960.1$ & $2,075.2$ & $2,168.0$ & $2,260.9$ & $2,316.9$ & $2,410.3$ \\
\hline
\end{tabular}

Source: Ministry of Agriculture (various years). 


\section{Industrial land allocation and rapid industrialisation}

After its reform and opening-up, China embarked a new path of industrialisation. This included industrialisation of collectively owned land in the countryside from the 1980s to the mid-1990s and the creation of industrial parks from the 1990s. This new pattern of industrialisation saw China become the world's factory, and its unique method of supplying industrial land played a significant role in this.

Surplus workers looking for employment after the agricultural land reforms drove rural industrialisation after the mid-1980s. The rigidities of the urban land system, and restrictions on the entry of rural labourers, meant the government could only permit peasants to build enterprises on collectively owned land. This required allowing collectively owned land to be entered into the nonfarming land market. Prior to the revision of the Land Administration Law of 1998, the two main forms of construction land use were in the countryside-peasants who built houses with their increased income following reform and those who built township enterprises on collectively owned land. Between 1993 and 1998, the amount of nonfarming construction land increased from 224,824 hectares to 367,854 hectares, while land for TVEs decreased from 13,943 hectares to 8,180 hectares (see Table 22.3). The advantage for peasants in developing enterprises on collectively owned land was that they did not have to pay for the land.

Rural enterprises solved the problem of land utilisation through land redistribution within the collective or by paying minimal rent for the use of collectively owned land. Rural industrialisation of collectively owned land radically changed the structure of national industrialisation. Until 1993, state-owned enterprises (SOEs), TVEs and foreign-owned enterprises each accounted for one-third of national gross output value (see Pei 2003).

Table 22.3 Statistics on the actual use of nonagricultural construction land (hectares)

\begin{tabular}{|l|c|c|c|}
\hline Year & $\begin{array}{c}\text { Nonagricultural } \\
\text { construction land }\end{array}$ & $\begin{array}{c}\text { Township collectively } \\
\text { owned construction land }\end{array}$ & Township enterprise land \\
\hline 1993 & 224,824 & 30,183 & 13,943 \\
\hline 1994 & 186,630 & 22,023 & 9,826 \\
\hline 1995 & 190,376 & 19,909 & 11,621 \\
\hline 1996 & 171,467 & 14,897 & 6,235 \\
\hline 1998 & 367,854 & 16,558 & 8,180 \\
\hline
\end{tabular}

Sources: Ministry of Land and Resources $(2004,2016)$.

After the mid-1990s, industrialisation on collectively owned rural land accounted for a large share of total cultivated land, caused environmental pollution and scattered industries. The Land Administration Law of 1998 brought into effect the 
institutional regulation of land use and gradually phased out the use of collectively owned land for nonagricultural construction. Industrial parks gradually replaced rural industrialisation as the main path to Chinese industrialisation and achieved particular success in eastern China and in parts of the central and western regions. The success of industrial parks was assisted by a distinctive land allocation pattern. First, the government used land to promote investment, providing land at low prices (and sometimes even for free or with negative rent). Second, local governments provided land for companies to carry out integrated development or to mortgage the land to a bank to fund construction. The industrial park would recoup value from revenue generated by the enterprises. Third, established enterprises in the park were provided with complete land use rights for 50 years. Enterprises could mortgage, sublease or transfer possession of the land, which stabilised their investment expectations and solved the financing demands for enterprise development.

Land is the secret to China's rapid industrialisation. If China had relied only on market allocation of land, the cost of industrial land would have been considerably higher than other land resources with better endowments, and rising land prices would have hindered industrialisation. Between 2000 and 2016, the national comprehensive land price increased at an average annual rate of 8.8 per cent, commercial services land prices increased by 9.6 per cent and residential land prices by 12.4 per cent. However, the average annual increase of industrial land prices has been only 3.5 per cent per annum (Table 22.4).

Table 22.4 Industrial land and industrial value added (per cent)

\begin{tabular}{|l|r|r|r|}
\hline Index & $\begin{array}{c}\text { Growth rate of industrial } \\
\text { value added }\end{array}$ & $\begin{array}{c}\text { Growth rate of land for } \\
\text { industrial and mining } \\
\text { warehouse space }\end{array}$ & $\begin{array}{c}\text { Growth rate of industrial } \\
\text { land price }\end{array}$ \\
\hline 2007 & 21.1 & -8.34 & 15.7 \\
\hline 2008 & 17.9 & -34.4 & 4.8 \\
\hline 2009 & 4.8 & 52.3 & 1.5 \\
\hline 2010 & 19.6 & 7.0 & 5.4 \\
\hline 2011 & 18.2 & 26.4 & 28.3 \\
\hline 2012 & 7.1 & 8.3 & -17.0 \\
\hline 2013 & 6.4 & 3.0 & 4.5 \\
\hline 2014 & 5.2 & 15.8 & 6.0 \\
\hline 2015 & 1.1 & -49.5 & 2.4 \\
\hline 2016 & 4.8 & -4.5 & 2.9 \\
\hline
\end{tabular}

Sources: Ministry of Land and Resources (2004, 2016). 


\section{Land capitalisation and rapid urbanisation}

After 2000, urbanisation in China accelerated. From 2000 to 2016, the urbanisation rate of the permanent resident population increased from 36.2 per cent to 57.4 per cent, growing at 2.9 per cent every year. Land capitalisation provided huge capital demand for urban construction. The linkage between local government maximisation of land profits and the rise in housing asset value was the major driving force for urbanisation.

First, the arrangement of bidding, auction and listing for commercial land increased the value of land capitalisation. Since 2003, the total area of land transacted by bidding, auction and listing in China is close to 4 million hectares, generating land revenue of RMB32 trillion. Land revenue in 2016 was 89 times as high as that in 2003 .

Second, huge demand for housing caused by housing commercialisation and rapid urbanisation in this period has maximised land revenue for local governments. From 2003 to 2016, newly added housing stock in China reached 26 billion square metres. Real estate loans to developers and residential purchase loans increased by 6.8 times from 2003 to 2016, while housing prices increased by 2.9 times. Rising premiums on land encouraged local governments to further increase their land revenue through bidding, auction and listing for commercial land. In 2001, the area of land sold by bidding, auction and listing accounted for 7.3 per cent of total land sold; in 2014, it had reached 92 per cent. The increasing revenue from land sales has, on one hand, provided financial resources for local governments to engage in urban infrastructure construction; on the other, it has encouraged local governments to increase urban expansion to generate even more capital from land. From 2000 to 2015, the urban construction area in China increased by 1.4 times (see Table 22.5).

Table 22.5 Land capitalisation and urban expansion, 2003-15

\begin{tabular}{|l|r|r|r|r|r|r|r|}
\hline Year & $\begin{array}{c}\text { Urbanisation } \\
\text { rate (\%) }\end{array}$ & $\begin{array}{c}\text { Urban } \\
\text { construction } \\
\text { area (sq m) }\end{array}$ & $\begin{array}{c}\text { Government } \\
\text { land sales } \\
\text { revenue } \\
\text { (RMB billion) }\end{array}$ & $\begin{array}{c}\text { BAL } \\
\text { area } \\
\text { (\%) }\end{array}$ & $\begin{array}{c}\text { Land } \\
\text { mortgage } \\
\text { area } \\
\text { (10,000 ha) }\end{array}$ & $\begin{array}{c}\text { Land } \\
\text { mortgage } \\
\text { value } \\
\text { (RMB } \\
\text { billion) }\end{array}$ & $\begin{array}{c}\text { Average } \\
\text { sale price of } \\
\text { commodity } \\
\text { housing } \\
\text { (RMB/sq m) }\end{array}$ \\
\hline 2003 & 40.5 & 28,308 & 542.1 & 27.8 & - & - & $2,359.0$ \\
\hline 2004 & 41.8 & 30,406 & 641.2 & 29.2 & - & - & $2,778.0$ \\
\hline 2005 & 43.0 & 32,521 & 588.4 & 35.1 & - & $3,167.7$ \\
\hline 2006 & 44.0 & 33,660 & 807.8 & 28.6 & - & - & $3,366.8$ \\
\hline 2007 & 44.9 & 35,470 & $1,221.7$ & 50.9 & - & $3,864.0$ \\
\hline 2008 & 45.7 & 36,295 & $1,026.0$ & 81.9 & 16.6 & $1,810.7$ & $3,800.0$ \\
\hline 2009 & 46.6 & 38,107 & $1,591.0$ & 85.3 & 21.7 & $2,585.6$ & $4,681.0$ \\
\hline 2010 & 47.5 & 40,058 & $3,010.9$ & 88.3 & 25.8 & $3,530.0$ & $5,032.0$ \\
\hline 2011 & 51.3 & 43,603 & $3,150.0$ & 91.3 & 30.1 & $4,800.0$ & $5,357.1$ \\
\hline
\end{tabular}




\begin{tabular}{|l|r|r|r|r|r|r|r|}
\hline Year & $\begin{array}{c}\text { Urbanisation } \\
\text { rate (\%) }\end{array}$ & $\begin{array}{c}\text { Urban } \\
\text { construction } \\
\text { area (sq m) }\end{array}$ & $\begin{array}{c}\text { Government } \\
\text { land sales } \\
\text { revenue } \\
\text { (RMB billion) }\end{array}$ & $\begin{array}{c}\text { BAL } \\
\text { area } \\
\text { (\%) }\end{array}$ & $\begin{array}{c}\text { Land } \\
\text { mortgage } \\
\text { area } \\
\text { (10,000 ha) }\end{array}$ & $\begin{array}{c}\text { Land } \\
\text { mortgage } \\
\text { value } \\
\text { (RMB } \\
\text { billion) }\end{array}$ & $\begin{array}{c}\text { Average } \\
\text { sale price of } \\
\text { commodity } \\
\text { housing } \\
\text { (RMB/sq m) }\end{array}$ \\
\hline 2012 & 52.6 & 45,566 & $2,690.0$ & 90.8 & 34.9 & $5,950.0$ & $5,791.0$ \\
\hline 2013 & 53.7 & 47,855 & $4,200.0$ & 92.3 & 40.4 & $7,760.0$ & $6,237.0$ \\
\hline 2014 & 54.8 & 49,773 & $4,294.0$ & 92.5 & 45.1 & $9,510.0$ & $6,324.0$ \\
\hline 2015 & 56.1 & 52,102 & $3,365.8$ & 75.2 & 49.1 & $11,330.0$ & $6,793.0$ \\
\hline
\end{tabular}

- no data available

Sources: CEINET Statistics database; Ministry of Land and Resources $(2004,2016)$.

Table 22.6 Land mortgage, cost and revenue, 2008-15

\begin{tabular}{|l|r|r|r|r|r|r|}
\hline \multirow{2}{*}{ Year } & \multicolumn{2}{|c|}{ Mortgaged land } & \multicolumn{2}{c|}{ Land cost } & \multicolumn{2}{c|}{ Land revenue } \\
\cline { 2 - 7 } & $\begin{array}{c}\text { Area } \\
\text { (10,000 } \\
\text { ha) }\end{array}$ & $\begin{array}{c}\text { Value } \\
\text { (RMB billion) }\end{array}$ & $\begin{array}{c}\text { Proportion of } \\
\text { expenditure } \\
\text { cost (\%) }\end{array}$ & $\begin{array}{c}\text { Cost proportion } \\
\text { in land } \\
\text { expropriation (\%) }\end{array}$ & $\begin{array}{c}\text { Actual input } \\
\text { (RMB billion) }\end{array}$ & $\begin{array}{c}\text { Net revenue } \\
\text { (RMB billion) }\end{array}$ \\
\hline 2008 & 16.6 & $1,810.7$ & 56.1 & 47.0 & 994.2 & 436.3 \\
\hline 2009 & 21.7 & $2,585.6$ & 53.8 & 44.5 & $1,424.1$ & 658.3 \\
\hline 2010 & 25.8 & $3,530.0$ & 58.4 & 49.6 & $2,939.8$ & $1,221.6$ \\
\hline 2011 & 30.1 & $4,800.0$ & 71.8 & 57.5 & $3,347.7$ & 942.3 \\
\hline 2012 & 34.9 & $5,950.0$ & 78.3 & 60.2 & $2,888.6$ & 626.1 \\
\hline 2013 & 40.4 & $7,760.0$ & 81.7 & 60.9 & $4,125.0$ & 755.1 \\
\hline 2014 & 45.1 & $9,510.0$ & 79.1 & 57.6 & $4,294.0$ & 898.8 \\
\hline 2015 & 49.1 & $11,330.0$ & 79.8 & 60.3 & $3,365.8$ & 681.3 \\
\hline
\end{tabular}

Sources: NBS (various years); Ministry of Land and Resources $(2004,2016)$.

Third, land financing provided more capital for urban development. Especially after 2008, various levels of government established financing platforms, and land mortgages significantly increased. From 2008 to 2015, the area and value of mortgaged land increased from 166,000 hectares and RMB1.8 trillion, respectively, to 490,800 hectares and RMB11.3 trillion (Table 22.6).

Using land to drive development has supported China's rapid economic growth, but China has become increasingly reliant on this rapid growth. High economic growth is part of a cycle of increasing investment attracted by land, increasing taxes and population, expanding urban areas, increasing real estate prices and increasing revenue from land sales, mortgages and loans. While strong growth continues, the cycle can be sustained; however, when the economy suffers a downturn, certain sections of this cycle are negatively affected, which influences national economic performance. This is mainly manifested as follows. 
First, the continuous increase in land supply no longer increases GDP. To deal with the GFC in 2008, China adopted looser fiscal and monetary policies, releasing land to prevent a possible economic downturn. Unfortunately, GDP growth reached a peak in 2009, and suffered a downturn thereafter. Although the loose supply in land lasted until 2013, the economic growth rate decreased from 10.6 per cent in 2009 to 7.8 per cent in 2013. After 2013, the economic downturn led to decreasing demand for land and a decreasing supply of construction land. The rapid economic growth rate of more than 10 per cent fell to a milder rate of 6-7 per cent, meaning that the mode in which economic growth will continue to be supported by loose land supply has gone forever (as shown in Figure 22.2).

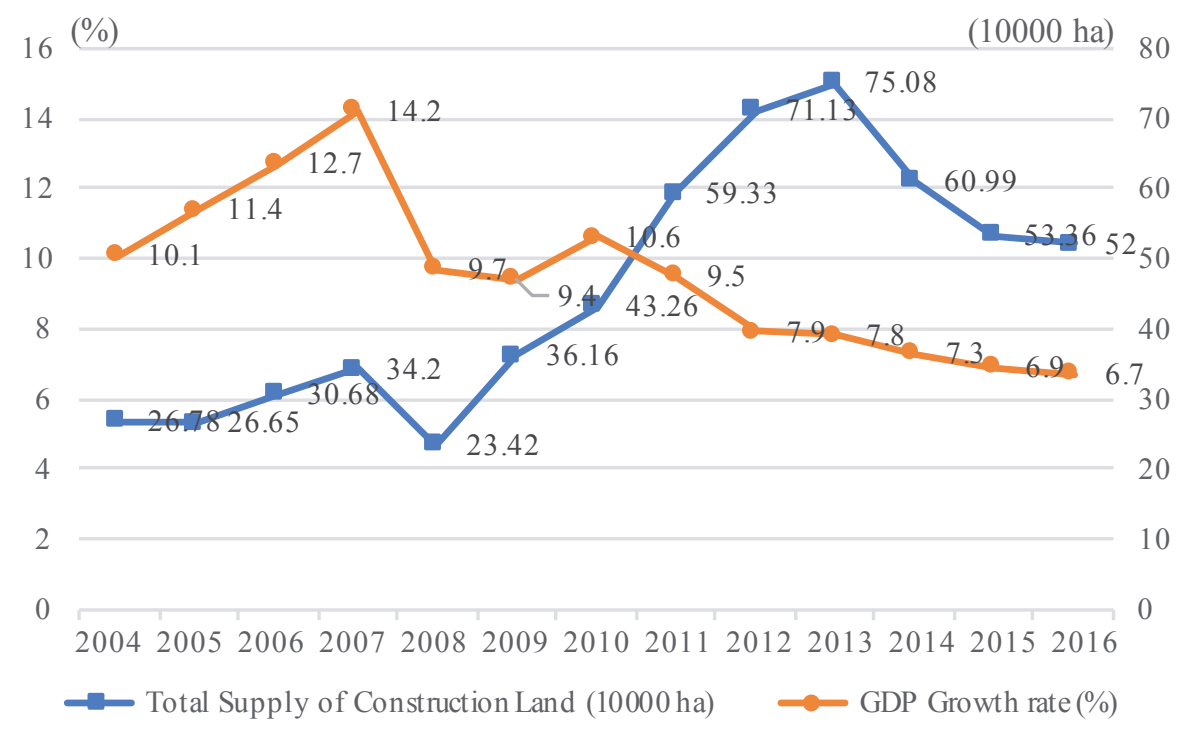

Figure 22.2 Relationship between land supply and GDP

Source: NBS (various years); Ministry of Land and Resources (2004, 2016).

Second, the efficiency of attracting investment through land is decreasing, and this mode of attracting investment for industrial parks started to change in 2004 . This is manifested in the decreasing amount of industrial land in eastern China (see Figure 22.3). The main reason for this is that as enterprises in the eastern areas have been transformed through quality improvement and industrial upgrading, they no longer rely so much on low land costs and land mortgage financing to acquire loans. Although the industrial parks in central and western China have imitated those in the east by attracting investment through land and the provision of excellent infrastructure, the efficiency of investment attraction for industrial parks in these areas is not good. On the contrary, such efforts have brought high levels of government debt. 


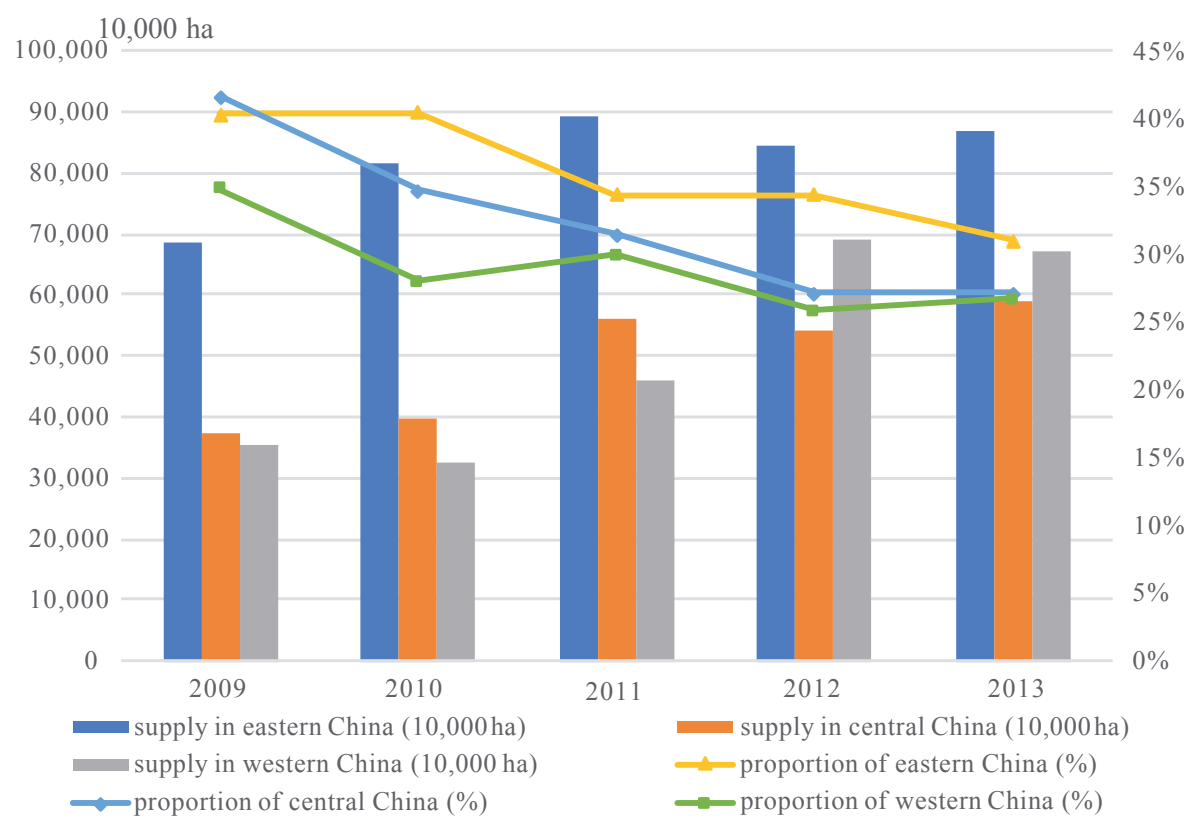

Figure 22.3 Supply structure of industrial land in different areas Source: NBS (various years); Ministry of Land and Resources (2004, 2016).

Third, the land supply structure is seriously distorted, which works against structural reform. In fact, the imbalance in land structure is the most serious structural problem in China. A high proportion of land for industry and infrastructure and a low proportion for real estate makes land a tool for government to attract investment and maximise land revenue. Since 2011, the proportion of industrial land decreased from 32.8 per cent to 23.4 per cent, in 2016 (Figure 22.4). Meanwhile, the proportion of real estate land also decreased, from 28 per cent to 6.7 per cent, which shows that local governments have not changed the system used to protect land revenue by controlling real estate land supply. A more serious problem is that the proportion of infrastructure land in this period increased from 38.8 per cent to 55.9 per cent-matching the increase in infrastructure investment. The growth rate of infrastructure investment reached 28.6 per cent in 2016. In circumstances in which the real economy suffers a downturn and real estate investment reaches a turning point, governments can only rely on a larger supply of infrastructure land and increased infrastructure investment to maintain economic growth, but these short-term measures actually delay structural reforms. 


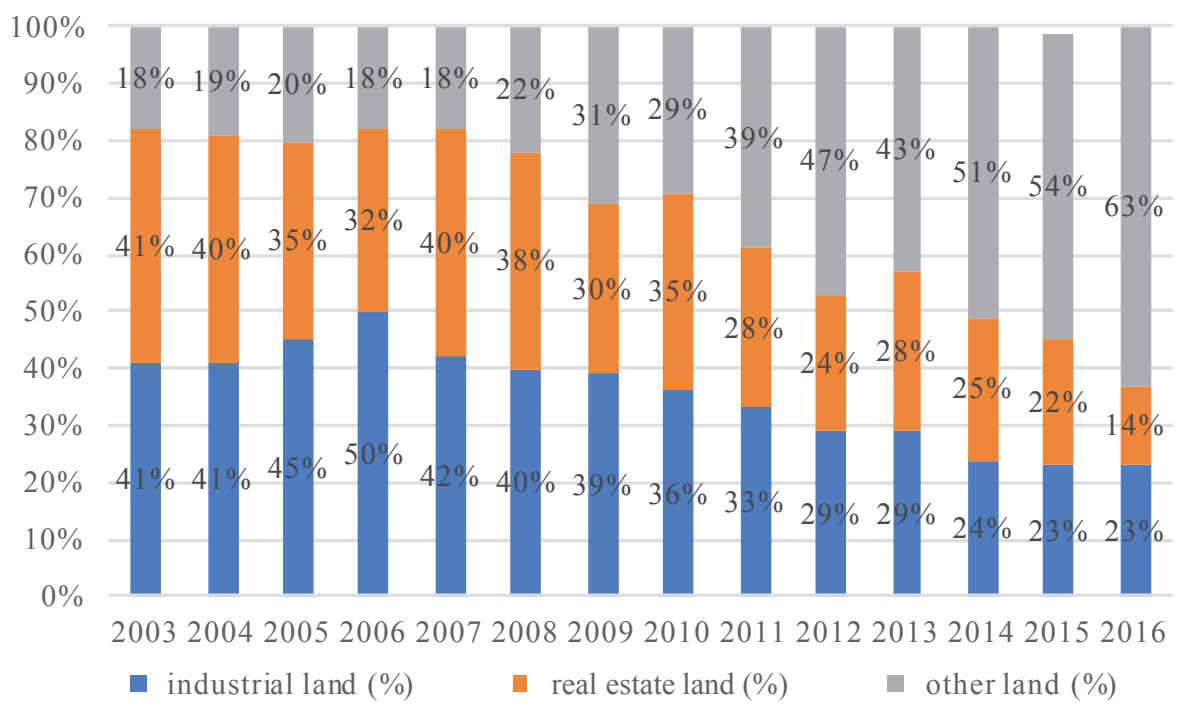

Figure 22.4 Supply structure of state-owned construction land

Source: Ministry of Land and Resources (2004, 2016).

Fourth, the sales cost of land has increased, net revenue from land has decreased and land mortgages have increased. Rapid urbanisation could be successfully completed in China. One important tool has been the low cost of land. The costs for the government to buy land have been low and most land revenue has been used for urban investment. But as land use in many cities has been transformed and farmers' awareness of their rights has awakened, land expropriation costs have substantially increased. Since 2008, the government's land sales cost has greatly increased, to above 50 per cent in many areas, and even above 60 per cent in others. The result is decreasing net land revenue for government, which was only 20 per cent in 2016. With decreasing net land revenue, the government is still increasing infrastructure investment and expanding construction of new areas in some cities. Government construction capital relies increasingly on land mortgages. From 2008, the area and value of mortgaged land increased from 166,000 hectares and RMB1.8 trillion, respectively, to 490,800 hectares and RMB11.3 trillion in 2016. The decrease in land revenue and increase in land mortgages mean higher financial debt risks.

Fifth, the government debt risk and bank finance risk have increased. First, the land mortgage value in many cities is evaluated when land prices are high. Once the economy suffers a downturn, demand for land will decrease and the gap between actual and estimated land values will be large. Second, from 2010 to 2015, the average proportion of land revenue in government debt reached 40 per cent. As land values are overestimated, local governments returned the debts after selling land for revenue. Third, there is excessive leverage. The nominal land leverage in midwestern 
China is high, while the actual leverage for most provinces in the midwest is over two times. Here, the leverage ratio refers to the level of land mortgage financing to local government revenue.

\section{Further land reform in the new development stage}

\section{Economic trends in the new development stage}

China's new stage of economic transformation will no longer rely so much on land. International experience suggests China's economic growth will inevitably decline, slowing from its high of 10 per cent over the past 30 years. The economic structure will also undergo a series of profound changes. The service industry has surpassed secondary industry, internal demand plays a more significant role and economic growth increasingly relies on improvements in production forces and innovation. Quality and efficiency have been greatly increased (Perkins 2015; Liu 2015). In this new development stage, land will no longer play a key role as an engine of growth and will instead bring negative effects. Measures to protect economic growth through loose land supply will no longer be necessary, and will instead waste increasingly rare resources. The significance of improving the quality of economic growth by enhancing land allocation efficiency is far greater than that of promoting economic growth by increasing land supply. How supply and allocation of land will meet the changing demands of economic growth will be a major issue for relations between land and the national economy in the future.

Second, industrial transformation and upgrading means industrial development will no longer rely so heavily on the system suppressing the cost of land. China has become the world's factory largely because of its low land costs, supported by an independent land system; however, as the relative prices of other factors and system costs increase, it will not be able to maintain this status. In field investigations, some regions, cities, industries and enterprises stand out for their level of transformation and upgrading. After a new round of industrial competition and upgrading, new competitive manufacturing cities, industries, enterprises and products will appear in China, replacing the current manufacturing supported by industrial parks and low land costs. The most competitive manufacturing areas will no longer rely on low land costs and land mortgages to resolve their funding issues - and those who cannot compete and who rely on low land costs will not be able to escape their destiny of being phased out. Therefore, the next round of manufacturing development in China will be about how to revitalise the existing stock of land and optimise land use for competition rather than protecting land supply. Another feature of industrial evolution is deep integration between the manufacturing and service sectors and 
increasing the share of the service sector. In 2013, the service sector's share in the Chinese economy exceeded that of manufacturing. The shares of value added in the primary and secondary sectors with respect to GDP were 46.7 per cent and 44 per cent, respectively. Unlike the manufacturing industry, the service industry does not require much land; this change in the industrial structure will weaken the role of land in future industrial development. The major policy issues in the future will be around land use structure, construction optimisation, industrial land reallocation, industrial park transformation and changes in land supply.

Third, the land allocation mode changes from a single focus on urbanisation to interaction between urban and rural areas. The road to urbanisation in China has so far been one of rapid flows of population, land and capital from rural to urban areas, influenced by the large gaps between the two areas. The next stage of urbanisation will need to shift focus to the relationship between urban and rural areas and increasing their interaction. So far the interaction between the two has been based on population flows from rural to urban areas. The public policies of the cities in which the population is living or working are difficult to implement and farmers' relations with their homelands are hard to sever. Farmers will work in areas with the greatest economic opportunities, and city living will be the first choice for much of China's population. At the same time, as interaction between urban and rural areas increases, more and more of the urban population will come to rural areas to experience rural life. Population interaction and exchange between urban and rural areas will be enhanced. Second, Chinese villages have become highly differentiated; while many are in decline, others are undergoing revitalisation. The growth of some small towns will help connect urban and rural areas. Some cities will succeed because of their factor agglomeration, diffusion and innovative vigour. Allocation and connection between dynamic cities, towns and villages will be enhanced. Third, while those with capital explore investment opportunities in urban areas, as rural development opportunities increase, some will also look for opportunities in agriculture and villages. Fourth, changes in consumption and population flows will increase opportunities as well as demand for land for rural development. Interaction between urban and rural areas will therefore replace the single-focus urbanisation and the population will flow between urban and rural areas.

Fourth, agricultural evolution and rural transformation will require a review of the value of village space. The greatest changes in the next stage of China's development will be a revolution led by rural areas. As China has entered the ranks of welloff societies, national food demand will shift from quantity to quality, and the importance of agriculture for food production will decrease. The function and pattern of agriculture will undergo significant changes. Rather than simply providing basic food, agriculture will specialise to focus on offering quality, safe and 'green' products. Opportunities for profit from agriculture will be greatly enhanced. China will need to redefine agriculture and recognise its new role. In addition, 
differentiation and having children bring structural revolution. Another feature of the changes in the farmer group is generational differentiation. The basic track for first-generation farmers is leaving their home area and then returning, while the second generation is leaving and not coming back. The latter's relations with land, conceptions of agriculture and behavioural features have undergone fundamental change. Further, the features of rural industries have changed. With changes in urban demand, many rural industries have been revitalised and expanded, while technological and commercial innovations have expanded the market scope for many rural craftspeople and local specialties. As such, many villages have become differentiated. Traditionally, Chinese villages depended on farming; but, as people's relationship with the land and the mode of agricultural development have changed, villages are becoming greatly differentiated. Some villages are revitalising with vigour and have taken on new functions in the interaction between urban and rural areas, while others are in decline or decaying.

\section{Land reform on the second half of the road to industrialisation}

The function of land as a driver of development is changing and will soon end. The most complicated issue in Chinese economic transformation is how to move away from the development mode driven by land. This mode is like opium: highly addictive and difficult to quit. Moving on will depend on whether the a development mode can improve production efficiency and drive innovation. The difficulty is that, if the existing mode is useful and still works, it will not be replaced with a new one. And, when a new mode cannot be established, we will have to return to relying on the old mode. The disadvantages of the land-driven mode of development are becoming increasingly obvious, but I believe the economic downturn provides the opportunity to change this longstanding development mode. The general conclusion is that the costs and revenue structure of the land-based development mode will no longer be profitable.

We have several suggestions for how to truly say goodbye to the land-based development mode. First, the central government should make it clear that land is not to be used for development or for macroeconomic control (when the economy is turning down, land is released; when the economy is growing, land is controlled). Advantage should be taken of the decrease in land demand during the economic downturn to cancel the system of land control targets and transfer to a strict planning system. Second, land's role as a development engine should be changed to avoid deliberate economic growth. Local governments should be prevented from using low land costs to attract investment; and overcapacity and repeated construction should be reduced. The system of local government land sales for to generate benefits must 
be changed, and uncontrolled expansion of urbanisation must be reduced. Third, reform should be made to the land market pattern that gives local governments an exclusive monopoly, to allow landowners to participate in the land market under regulation. Fourth, the system by which local governments use land for financing should be reformed. Fifth, all land debts should be erased at once. The sixth suggestion is to build a national land operation company and ensure governments acquire a certain amount of revenue through its operation. Seventh, differentiated real estate taxes should be collected from land used for different functions.

Once the role of land as a driver of development ends, optimisation of the land structure will promote national economic structural reform. This can be done by reducing the supply of public land for infrastructure and the use of land to attract investment as a means of promoting economic growth. After nearly 30 years, the peak of massive investment in infrastructure in China is over. It is not right to increase infrastructure investment simply to protect the level of investment and growth, as this will cause further structural distortions. Expropriating large parcels of land for infrastructure will not only increase government expenditure, but also increase the conflict between governments and the farmers whose land is expropriated. The proportion of public land in urban areas is excessively high, and it is used for high-profile projects such as roads, public squares and large office buildings. This not only wastes large amounts of capital and land, it also causes the diversion of liveable and development sites in the cities.

Compared with international experience, China's land usage structure sees industrial land accounting for the highest proportion of land. Although this proportion has decreased in recent years, it is still excessively high. With economic structural optimisation and transformation and upgrading of the manufacturing industry, there is still much room to lower the proportion and supply of industrial land. This will be a major aspect of land allocation restructuring in the next period of reform. Instead of using low-cost land to attract investment to industrial parks, authorities should promote the transformation and upgrading of these parks. Industrial parks have made a significant contribution to China's development and helped it become the world's manufacturing plant. However, this has also distorted prices for industrial land. Enterprises occupy excessive amounts of land because of its low cost, and industrial parks speculate on land. Such drawbacks are becoming quite obvious in midwestern China. We must change the current method of attracting investment through low land costs and find a balance between investment and tax in the excessive infrastructure construction for industrial parks. We must then reduce the number of such parks, and merge those that are performing poorly.

Next, we should increase the proportion of land allocated for real estate, changing the supply of land for housing and restricting real estate market bubbles. Generally, we should increase the supply of land for housing and the proportion of housing land in total construction land. Different supply methods should be used for land 
for investment housing and for residential housing. The system of bidding, auction and listing should continue. Land and housing prices should be entirely allocated by the market, while the government allocates residential land. Affordable housing for residential use should be separated from that for investment purposes. A market for land for collective construction for villages or areas surrounding cities should be established, with farmers allowed to build and rent houses collectively using collective construction land. A benefit-sharing mechanism should be created for the structural optimisation of construction land.

So far, the relationship between urban and rural areas has been focused solely on urbanisation. The important supportive system is the land transfer system for urban and rural areas. Rural land can only become urban construction land through expropriation and nationalisation. Farmers and villages will lose land development rights. The loss of village development rights will cause rural labour migration, land allocation towards urban areas and fewer profit opportunities for capital in rural areas. To realise the interaction between production factors in urban areas and those in rural areas in China, we must reform urban and rural land allocation systems and allow farmers' collective land to enter the construction land market under regulation. We should realise the same rights for two kinds of collective land. This is the most important reform in terms of deciding whether China has truly become urbanised. It will play a decisive role in the sustainability of the Chinese development mode and the realisation of Chinese modernisation. Substantial reform consists of, first, reforming the land requisition system, and of improving the public interest in land management laws. This includes changing the original use principles for expropriated land, gradually implementing land market price compensation and implementing equitable prices and compensation rights for houses expropriated in urban and rural areas. Second is to implement the spirit of land reform raised in the third plenary session of the eighteenth National Congress, build an integrated market for construction land in urban and rural areas and establish construction land for collective operation that conforms to general land planning rules. Collective landowners should be allowed to transfer land by leasing, selling or becoming a shareholder. The use right for collective construction land can be used for transfers, rent and mortgages.

The promotion of farmland reform should centre on the separation of the three powers of collective ownership, contract rights and operation rights-clear definition of which will be key to innovation and farmland allocation. This is related to the method of restructuring the system of farming land rights and agricultural modernisation. First is to define collective ownership as ownership rights for collective farmers. Insist on collective farmers as the main body for collective land ownership. Village collective economic organisations or village committees, groups or farming collective organisations should only represent collective farmers to implement landownership. Second, the land contract right is the property right for 
collective members. Land contracts provide the legal rights for the possession and use of and income from contracted land, and can include transfers, swaps, renting (subcontracting), becoming a shareholder and winning profits. The contracting land operation right can be mortgaged, and contracted lands can be withdrawn voluntarily. Third, the land operation right is the farming right enjoyed by all kinds of agricultural management entities. The purpose of the land operation right is to provide holders with stable land use and investment expectations.

In the whole system of rural land reform, the most influential component for agriculture is land operations.

\section{Conclusion}

After 40 years of reforms and opening up, China has not only created a growth miracle unparalleled in human history, but also transformed itself from a rural to an urban society. Behind this great transformation is a systemic reform of land institutions. Rural land institutions moved from collective ownership to the household responsibility system, thereby protecting farmers' land rights. This process resulted in long-term sustainable growth in Chinese agriculture, massive ruralurban migration and unprecedented agricultural transformation. The conversion of agricultural land to nonagricultural uses and the introduction of market mechanisms made land a policy tool in driving high economic growth, industrialisation and urbanisation. However, we need to recognise that the role of land and its relationship with the economy will inevitably change as China's economy enters a new stage of medium-high-speed growth. With economic restructuring, low-cost industrial land will be less effective. Urbanisation is also shifting from rapid expansion to endogenous growth so that returns on land capitalisation will decrease and risks will increase. Therefore, China must abandon its land-dependent growth model through deepening land reforms and adapt a new pattern of economic development.

\section{References}

Central Committee of the Communist Party of China (CPC Central Committee) (1982), Summary of the National Rural Work Conference, 1 January, Beijing: General Office of the State Council.

Central Committee of the Communist Party of China (CPC Central Committee) (1984), Circular of the Central Committee of the Communist Party of China on Rural Work in 1984, 1 January, Beijing: General Office of the State Council. 
Central Committee of the Communist Party of China (CPC Central Committee) (1992), Circular of the State Council on several issues concerning the development of real estate industry, Guofa (61)(4 October).

Central Committee of the Communist Party of China (CPC Central Committee) (1993), A Number of Policy Measures Promulgated and Implemented by the Central Committee of the Communist Party of China and the State Council on the Current Agricultural and Rural Economic Development, 5 November, Beijing: General Office of the State Council.

Central Committee of the Communist Party of China (CPC Central Committee) (1998), Decision of the Central Committee of the Communist Party of China on Some Major Issues Concerning Agriculture and Rural Work, 14 October, Beijing: General Office of the State Council.

Central Committee of the Communist Party of China (CPC Central Committee) (2008), Decision of the Central Committee of the Communist Party of China on Some Major Issues Concerning Promoting Rural Reform and Development, 12 October, Beijing: General Office of the State Council.

Central Committee of the Communist Party of China (CPC Central Committee) (2011), Decision of the Central Committee of the Communist Party of China on Some Major Issues Concerning Comprehensively Deepening the Reform, Beijing: People's Publishing House.

Central Committee of the Communist Party of China (CPC Central Committee) (2013), Decision of the Central Committee of the Communist Party of China on Some Major Issues Concerning Comprehensively Deepening the Reform, 12 November, Beijing: General Office of the State Council.

Du, R. (2005), An Account by Du Runsheng: A record of significant decisions on the reform of Chinese rural institutions, Beijing: People's Publishing House.

Fei, X. and Liu, H. (2007), From the Soil, Shanghai: Shanghai People's Publishing House.

Liu, S. (2002), Statement concerning the Law of the People's Republic of China on Land Contract in Rural Areas, [draft], 26 June 2001, Twenty-Second Session of the Standing Committee of the Ninth National People's Congress, Beijing.

Liu, S. (2008a), China's dualistic land rights system and land market incompleteness: Review and comment on current policy, law and local innovation, Review of Economic Research (31): 2-12. 
Liu, S. (2008b), Collective land capitalization and rural urbanization: A Survey of Zheng Ge Zhuang village in Beijing, Journal of Peking University (Philosophy and Social Sciences Edition) (6): 123-32.

Liu, S. (2012), Risks and reform of land-based development model, International Economic Review (2): 92-109.

Liu, S. (2015), Ten Years' Outlook for Chinese Economic Growth 2015-2024, Beijing: China CITIC Press.

Mao, Z. (1961), Report on the Second Plenary Session of the Seventh Central Committee of the Communist Party of China, Beijing: Foreign Languages Press.

Ministry of Agriculture (various years), Agricultural Statistics of the People's Republic of China, Beijing: Chinese Agricultural Press.

Ministry of Land and Resources (2002), Provisions on the Assignment of State-owned Land Use Rights by Means of Bid Tendering, Auction and Listing, Decree No. 11, Beijing: Chinese Agricultural Press.

Ministry of Land and Resources (2004), China Land and Resources Bulletin 2004, Beijing: Chinese Agricultural Press.

Ministry of Land and Resources (2016), China Land and Resources Bulletin 2016, Beijing: Chinese Agricultural Press.

National Bureau of Statistics (NBS) (various years), China Statistical Yearbook, Beijing: China Statistics Press.

Pei, X. (2003), The contribution of collectively-owned land ownership to economic transition in China and countryside industrialization: An explanation of a resource allocation model, in H. Zongzhi (ed.), Study on Chinese Countryside. Series 1, Beijing: The Commercial Press.

Perkins, D. (2015), East Asian Development: Foundations and strategies, Beijing: China CITIC Press.

Qu, D. (2015), China Agriculture Statistical Report, Beijing: Chinese Agricultural Press.

Rural Development Group (1984), Systematic Review of Rural Economic System Reform in China, Chinese Social Sciences Press: Beijing.

State Council (2004), Urgent circular of the General Affairs Office of the State Council on properly solving the current rural land contract disputes, Telegram No. 21, 30 April, Beijing: General Office of the State Council. 
State Council (2014), Opinions on rural land expropriation, putting collectiveowned operational construction land into market, homestead system reform pilot work, Zhongbanfa (71).

State Council (2015), Decision to Authorize the State Council to Temporarily Adjust the Relevant Legal Provisions in the Administrative Areas of the 33 Pilot Counties (Cities and Districts) in Daxing District, Beijing, NPC Regular Session No. 1, Beijing: General Office of the State Council.

Wang, L. and Zhou, Y. (2012), On the perfection of rural land property rights system in China, China Legal Science (1): 45-54.

Zhou, Q. (1995), Reform in China's countryside: Changes to the relationship between the state and ownership (second part) - A review of the history of economic system change, Management World (4).

Zhou, Q. and Liu, S. (1997), Meitan: Land tenure change in a traditional agricultural county, in Land System Construction, Experimentation, Monitoring and Evaluation, Guiyang: CPC Guizhou Provincial Committee Policy Research Office and Guizhou's Meitan County Committee of the CPC. 
This text is taken from China's 40 Years of Reform and Development: 1978-2018, edited by Ross Garnaut, Ligang Song and Cai Fang, published 2018 by ANU Press, The Australian National University, Canberra, Australia.

doi.org/10.22459/CYRD.07.2018.22 